\title{
O processo arqueológico do intérprete-criador
}

Amanda Gonsales de Araujo (IC)

Prof $^{-}$Dra. Regina Machado (Orientação)

\section{Resumo}

Essa pesquisa é fruto do intercâmbio de seis meses da artista-pesquisadora para Évora, Portugal. Lá, alguns temas emergiram de forma potente, ocasionando um desejo de aprofundá-los e associá-los a um processo de criação artística. Entende-se, portanto, essa pesquisa, como uma oportunidade de unir conceitos já estudados, que tinham como foco a formação da expressividade do artista em cena, com um processo criativo que parte de memórias, experiências e temas humanísticos. Essa pesquisa resume-se, então, como uma investigação arqueológica vocal, corporal e criativa, que encontra na criação cênica um meio para manifestar-se, gerindo como produto final a confecção de um espetáculo cênico-musical.

Palavras chave: Canto, Corpo, Processo criativo.

\section{Introdução}

A experiência de ter vivido por um semestre em Portugal, provocou-me reflexões profundas e um potente encontro comigo mesma. Tal processo, permitiu tornar-me muito mais atenta ao que me rodeava, fazendo-me vislumbrar um processo de criação artística partindo dessa vivência. Refletindo sobre a ideia da arqueologia (escavar e encontrar para compreender) comecei a associá-la com esse processo de imersão que eu estava vivendo.

A partir disso, temas sobre a existência humana passaram a me abarcar mais e mais e o desejo de poder comunica-los foi o que me moveu para a criação e desenvolvimento desse espetáculo. Com isso, estruturaram-se os temas sobre os quais trataríamos, e a partir disso foi construída a dramaturgia, sustentada por canções, textos e ações que dialogavam com o público. Realizamos o ensaio aberto, analisamos e reconstruímos o espetáculo que foi apresentado um ano depois, o que nos permitiu refinar aspectos vocais e dramatúrgicos, buscando assim, potencializar o fazer artístico.

\section{Resultados e Discussão}

Após a realização do ensaio aberto ponderamos o que teria de ser alterado para o refinamento do espetáculo. Modificamos o local, a instrumentação, as canções e os textos, porém os temas a serem tratados permaneceram os mesmos. Para a apresentação do espetáculo final, convidamos um diretor de teatro para integrar a equipe e assim refizemos a dramaturgia, buscando destacar as temáticas abordadas. Como resultado final, o espetáculo teve grande aceite por parte do público, efetivando assim o que se propôs: fazer chegar ao público a intensa experiência emocional vivenciada pela pesqusiadora.

Figura 1. Espetáculo Um olhar de lua atravessado de nuvens

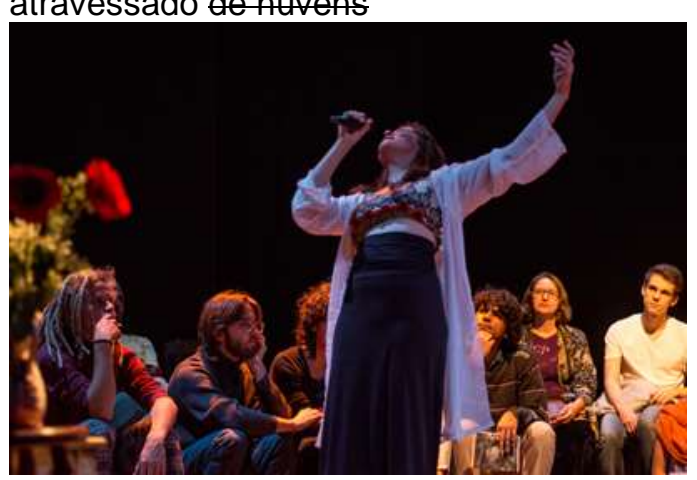

Conclusões

Construir um espetáculo partindo de vivências pessoais proporcionou que eu pudesse me expressar por inteiro e, consequentemente, ter algo a partilhar com aquele que vê. Voz e corpo deram vida a essa criação, em busca de proporcionar reflexões para o espectador. Investigar cada vez mais a fundo um caminho potente de expressão e criação, é meu intuito como artista e pesquisadora.

\section{Agradecimentos}

À equipe que fez parte do ensaio aberto e do espetáculo apresentados como fruto dessa pesquisa.

Hilst, Hilda. Tu não te moves de ti. São Paulo. Editora Globo, 2004

Sanmartin. Stela M. Arqueologia da Criação Artística. Vestígios de uma gênese: o trabalho artístico em seu movimento. Dissertação de mestrado, Unicamp, Instituto de Artes, 2004. 